Eurasian Journal of Soil Science

Journal homepage : http://ejss.fesss.org

\title{
Assessing aggregate stability of soils under various land use/land cover in a watershed of Mid-Himalayan Landscape
}

\author{
Abhisek Kumar Singh, Suresh Kumar, Justin George Kalambukattu *
}

Agriculture and Soils Department, Indian Institute of Remote Sensing, ISRO, Uttarakhand, India

\begin{abstract}
Soil aggregate stability is considered as an important indicator of soil quality in the landscapes witnessing land degradation due to soil erosion by water. An increase in anthropogenic activities over the period of time has accelerated soil erosion that necessitated need to assess soil aggregate stability in various land use/land cover in the hilly and mountainous landscape. The study investigated the soil aggregate stability of surface soils in different land use/ land cover classes, hillslope unites as well as in respect to terrain parameters in the watershed. The watershed located in mid- Himalayan region of Tehri Garhwal district, Uttarakhand, India covering an area of 196 ha. The elevation of the watershed ranges from $1200 \mathrm{~m}$ to $1927 \mathrm{~m}$. CartoDEM was used to derive terrain parameters i.e., aspect, slope and terrain indices like Terrain Wetness Index (TWI) and Stream Power Index (SPI) of the watershed. Among the various land use /land cover classes, aggregate stability in crop land was found to be in the range of 0.16 (lower hillslope) to 0.28 (mid hillslope), in forest ranged from 0.18 (mid hillslope) to 0.28 (upper hillslope) and in dense scrub ranged from 0.16 (middle slope) to 0.32 (upper/lower hillslope). The aggregate stability was further analyzed in relation with various soil (carbon, nitrogen, sand, silt, clay and $\mathrm{pH}$ ) and terrain (slope, elevation, TWI and SPI) variables. Among these variables soil carbon, nitrogen, elevation, TWI and SPI were found to have moderate to high degree of correlation with soil aggregate stability. Prediction model developed by using the various significant soil and terrain parameters were found to be more effective $(\mathrm{r} 2=0.50)$ than the models developed using only soil parameters ( $\mathrm{r} 2=0.36$ ) or only terrain parameters ( $\mathrm{r} 2=0.37$ ).
\end{abstract}

Keywords: Land Use/ land cover, Mid-Himalaya, soil aggregate stability, terrain parameters.

(C) 2019 Federation of Eurasian Soil Science Societies. All rights reserved

\section{Introduction}

Aggregate stability of a soil is the measure of the resistance of soil structure against mechanical or physicochemical destructive forces. Soil structure is closely associated with soil characteristics like soil water regime, soil nutrient availability and soil erodibilty (Shaver et al., 2002). Aggregate stability is considered to be one of the main soil properties controlling soil erodibility (Cerdá, 1996). It is one of the major factors influencing plant growth by its adverse impact on root penetration, soil temperature and gas diffusion, water transport and seedling emergence. Increase in aggregate stability reduces the soil loss and ingresses the quality of macro-aggregates and total and effective porosity. It also helps in reducing the loss of carbon, nitrogen and phosphorous (Kasper et al., 2009).

Gülser (2006) observed decrease in the proportion of micro aggregates in the fractions $0.5 \mathrm{~mm}$ in size and increased the proportion of macro aggregates in the fractions $1.00 \mathrm{~mm}$ in size in various forage cropping treatments. He found significant increase in organic carbon (OC) content and aggregate stability in various

\footnotetext{
${ }^{*}$ Corresponding author.

Agriculture and Soils Department, Indian Institute of Remote Sensing, ISRO, 4 Kalidas Road, Dehradun, 248001 Uttarakhand, India

Tel.: +914312407088

E-mail address: justin@iirs.gov.in

e-ISSN: 2147-4249 DOI: $10.18393 /$ ejss.541319
} 
forage cropping treatments in comparison to the fallow control treatment. Zhu et al. (2017) reported positive correlation of soil organic carbon (SOC) with soil aggregate stability index in natural restoration grassland whereas opposite in Chinese red pine forest.

Erosion primarily hinders the development of soil structure. Since aggregates can only be made when there is limited loss of finer particles and cementing agents (Shi et al., 2010). Several studies had described the relationship between the aggregate stability indices and soil erosion (Le Bissonnais, 1996; Cantón et al., 2009). It is a vital and critical component of soil erodibility as it regulates the soil dispersion and surface seal development. Soil aggregate stability directly or indirectly related to soil erosion and degradation (Barthès et al., 1999; Tejada and Gonzalez, 2006; Mataix-Solera et al., 2011) performed a study on amended soils and suggested to adopt both erodibility and structural stability as a measure of soil vulnerability. Field investigation of soil susceptibility to water erosion is generally an expensive and time taking process (Barthès and Roose, 2000). Therefore, determining its relationship with soil aggregate stability is rather cheaper and easier approach to enable characterizing soil aggregation which can further be extended to investigate its susceptibility (Poch and Antúnez, 2010).

Several studies had focused on establishing relationship between organic carbon, soil erosion and the role of soil aggregation in organic carbon protection in different landscapes (Six et al., 2004; Berhe et al., 2007; Yadav and Malanson, 2007). Certain factors like temporal and spatial heterogeneity and complexity in soil continuum make it really difficult to measure aggregation and carbon storage in soil (Bronick and Lal, 2005). Water test of aggregate is discrete and indirect method to estimate aggregation which is a simple and fast way to understand the management effect on aggregation and carbon storage. (Shrestha et al., 2007) studied the relationship between soil aggregate stability and land use systems. The study showed that different land use systems and management practices have a significant impact on the soil's properties, especially organic carbon and soil aggregation. Soil aggregate stability can be substantially enhanced by increasing the organic carbon content which is more profound in soils having higher clay content. Soils with high organic matter and clay content develop better soil structure that ultimately provides high resistance to water erosion (Emadodin et al., 2009).

Topography is the key soil forming factor in climatically and geologically homogenous areas. It plays a significant influence on a wide range of soil physical and chemical properties (Gerrard, 1981). Quantitative topographic data are widely applied in studies to understand how topography influences the soil properties (Kumar and Singh, 2016). Digital Elevation Models (DEMs) are commonly being used for extracting terrain parameters of the landscape. Currently, global DEMs such as Shuttle Radar Topography Mission (SRTM) (version 4, C-Band DEM of 3 arc-second, $90 \mathrm{~m}$ resolution) and the Advanced Space borne Thermal Emission and Reflection Radiometer (ASTER) (version 2, $30 \mathrm{~m}$ resolution) are available to the global users. However, CartoDEM (30 m resolution) is available for Indian Peninsula (Jain et al., 2017). High resolution provides improved estimation of terrain variables and help in better characterization of morphometric parameters of watershed and soil properties (Case et al., 2005; Hancock et al., 2006; Smith et al., 2006; Anornuet al., 2012; Das et al., 2016). Several studies have used ASTER, SRTM and Cartosat DEM with 30 to $90 \mathrm{~m}$ resolution in predicting soil parameters for small and large area (Saran et al., 2010; Ballabio et al., 2016). Terrain attributes are usually used regardless of the study scale or DEM resolution and are associated with the mathematical sense of particular variables (Florinsky, 2012). Kienzle (2004) compared terrain variables on $100 \mathrm{~m}$ elevation points with high resolution DEM and reported that elevation and slope has strong positive relationship while other terrain derivatives were not represented very well when derived from a coarse DEM.

Terrain attributes such as slope, aspect, Terrain Wetness Index (TWI) and Stream Power Index (SPI) are closely associated with the spatial heterogeneity of aggregate stability through their impact on various soil properties (Rhoton and Duiker, 2008). TWI is a study state wetness index its higher values represent drainage depressions, lower values represent crests and ridges and SPI used to describe potential flow erosion at the given point of the topographic surface. However, there are few studies concentrating on the soil aggregate stability and its relationship with terrain attributes. There are few studies conducted on the assessment of soil aggregate stability in various parts of the hill landscape systems (Rhoton et al., 2006; Tang et al., 2010) considering their direct relationship with topographic derivatives (Cantón et al., 2009). However studies exploring such relationships are rarely been conducted and reported from the fragile ecosystems of North West Himalayan region. Soils of the Himalayan region are very young and very prone to erosion. These soils have poor structural development. The present study was aimed to investigate the soil aggregate stability in different land use/ land cover as well as to assess the soil aggregate stability in relation to soil properties and terrain attributes of the watershed. 


\section{Material and Methods}

\section{Description of the study area}

The study was carried out to study soil aggregate stability under various land use/land cover in a watershed represent mid-Himalayan region of Tehri Garhwal district of Uttarakhand state in India (Figure 1). The watershed is located at longitude of $78^{\circ} 25^{\prime} 2.556^{\prime \prime} \mathrm{E}$ to $78^{\circ} 24^{\prime} 1.2^{\prime \prime} \mathrm{E}$ and Latitude of $30^{\circ} 21^{\prime} 31.87^{\prime \prime} \mathrm{N}$ to $30^{\circ} 21^{\prime} 21.51^{\prime \prime} \mathrm{N}$ covering an area of 196 ha. The elevation in the watershed ranges from 1200 to $1927 \mathrm{~m}$. The region is characterized as humid sub-tropical. The minimum and maximum mean temperatures in the region are $4.6^{\circ} \mathrm{C}$ in winter and $33.5^{\circ} \mathrm{C}$ in summer, respectively. The average annual rainfall is $1400 \mathrm{~mm}$. The entire watershed consists of high hills and ridges which are deeply incised by the streams. The hilly landform of the watershed has been divided into upper, middle and lower hillslopes (Figure 2). The soils of the watershed is characterized as excessively drained to well drained and containing slight to moderate coarse fragment in the surface layer. Soils are shallow to moderately deep and sandy loam to loam in texture (Table 1, Figure 3).

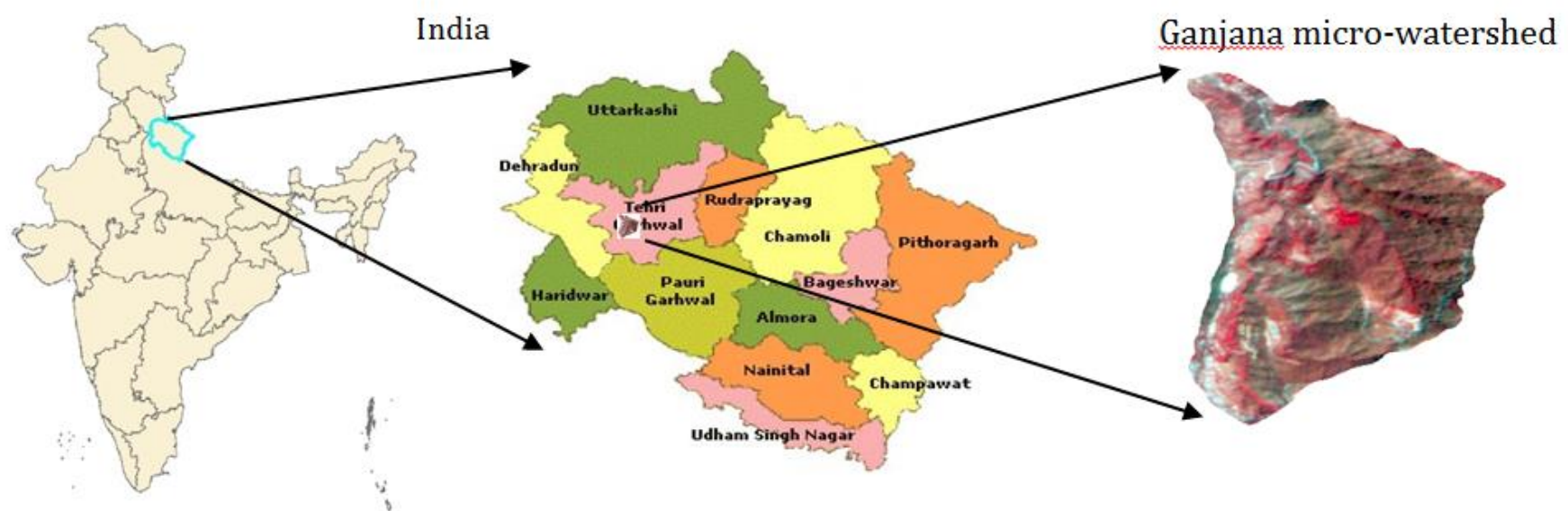

Figure 1. Location of the study area

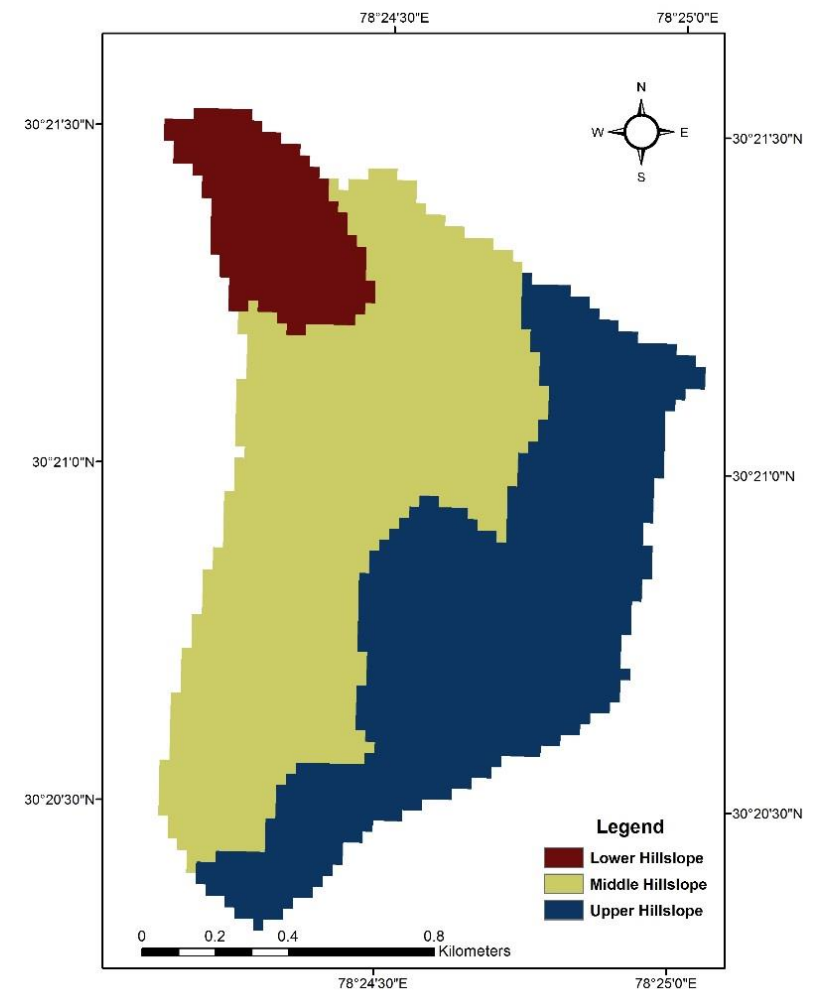

Figure 2. Landform map showing various hillslope units in the watershed

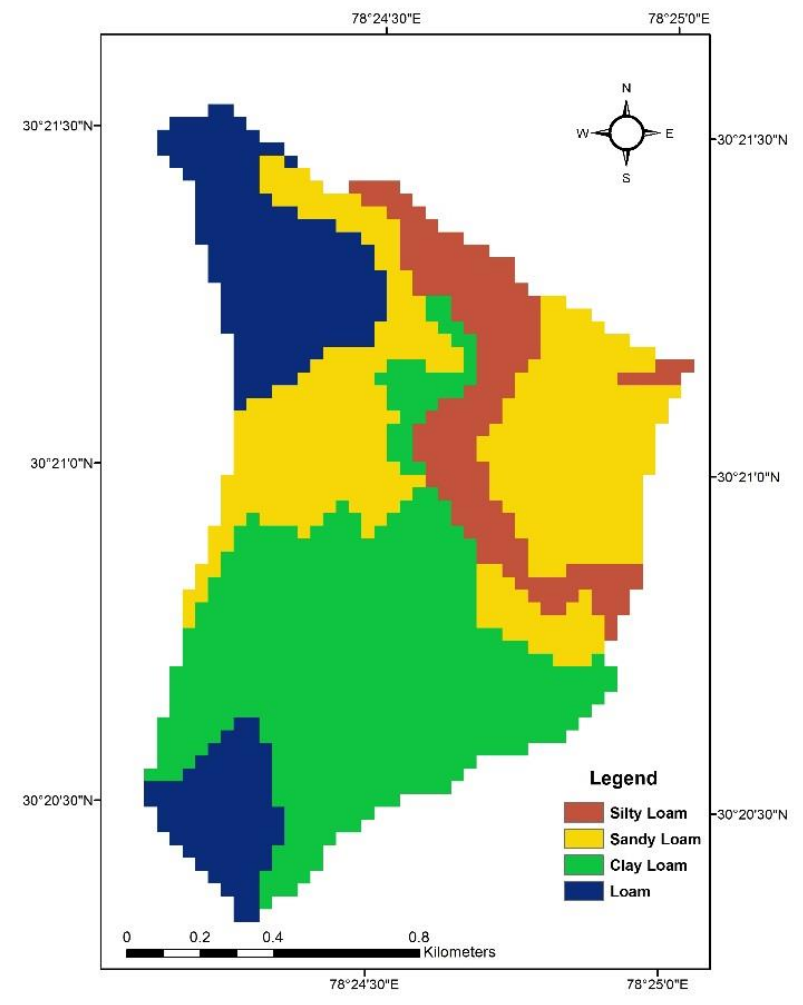

Figure 3. Soil textural class map of the watershed 
Table 1. Site characteristics and physico-chemical properties of soils in the study area

\begin{tabular}{ccc}
\hline S. no. & Variables & Range of Characteristics \\
\hline 1 & Elevation (MSL) & $1200-1927 \mathrm{~m}$ \\
2 & Slope class & Undulating to very steep \\
3 & Soil Texture Class & Sandy Loam to Loam \\
4 & Soil Depth class & Shallow to moderate deep \\
5 & Drainage class & Well to Excessive \\
6 & Erosion class & Moderate to severe \\
7 & $\mathrm{pH}$ & $5.3-7$ \\
8 & EC & $0.02-0.66 \mathrm{dS} / \mathrm{m}$ \\
9 & Total soil Carbon & $1.2-3.28 \%$ \\
10 & Total soil Nitrogen & $0.05-0.55 \%$ \\
\hline
\end{tabular}

\section{Data Used}

Resourcesat-1 LISS-IV data was used to prepare land use land cover of the watershed by on screen visual interpretation at 1:25,000 scale. CartoDEM derived from Cartosat-1 satellite having a spatial resolution of 10 $\mathrm{m}$ was used to generate terrain indices like Stream Power Index (SPI), Terrain Wetness Index (TWI) and terrain parameters like aspect and slope. The CartoDEM was downloaded from website http://bhuvan.nrsc.gov.in/data/download/index.php. The DEM has vertical accuracy of 8 meter (Santillana et al. 2016). The salient characteristics of satellite data and DEM used in the study are given in (Table 2). The google earth image of the study area used for detailed understanding and preparation of the field plans.

Table 2. Salient characteristics of satellite data and DEM used in the study

\begin{tabular}{ccccccc}
\hline Satellite & Used & Date of & \multicolumn{3}{c}{ Resolution } & \multirow{2}{*}{ Source } \\
data & for & acquisition & Spatial $(\mathrm{m})$ & Radiometric & Temporal nn & NRSC data center \\
\hline Resourcesat-2 & $\begin{array}{c}\text { Land use/land } \\
\text { LISS-IV }\end{array}$ & $18 / 5 / 2016$ & 5.8 & 10 & 5 & \\
\hline Carto-DEM & $\begin{array}{c}\text { Terrain } \\
\text { characterization }\end{array}$ & $27 / 5 / 2016$ & & 10 & & $\begin{array}{c}\text { bhuvan.nrsc.gov.in } \\
\text { /data/download/ }\end{array}$ \\
\hline
\end{tabular}

\section{Methodology}

\section{Soil sampling}

The watershed was classified into upper, middle and lower hillslopes based on elevations. Three number of transects were selected for soil sampling corresponding lower to upper hillslope positions with various land use/ land cover. Field sites were identified to collect soil sample in each hillslope of 0 $20 \mathrm{~cm}$ depth (Figure 4). There were 15 no. of soil sample were collected from each hillslope unit accounting total 45 no. of soil samples in July 2016. The geographic coordinates were recorded using GPS. Soil sample were analyzed for soil aggregate stability and their physico-chemical properties. The soil samples were processed and soil texture (sand, silt and clay contents) was estimated by using Bouyoucos hydrometer method (Kroetsch and Wang, 2007). The total soil carbon (TC) and total nitrogen (TN) were estimated using CHNS elemental analyzer (Vario MICRO cube, Elementar Inc., Germany). Soil pH (1:2) was measured using a pHmeter.

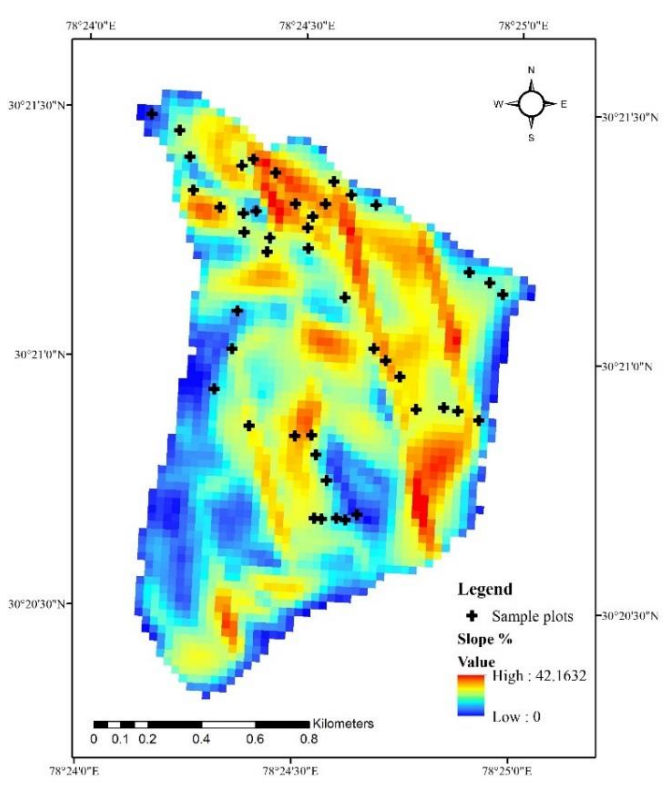

Figure 4. Slope map of the study area showing the field sample point

\section{Soil aggregate stability analysis}

The aggregate stability was analyzed using Wet Sieving Apparatus following the procedure described by (Nimmo and Perkins, 2002). Aggregates were determined on 2-mm sieved, air dried soil samples of $4 \mathrm{~g}$, pre- 
moistened the aggregates for 5-10 minutes. The sample was then wet-sieved using a motor -driven holder lowering and raising $0.25-\mathrm{mm}$ sieves in containers of deionized water, the stroke length was $1.3 \mathrm{~cm}$ and sieving frequency was 34 cycles min $^{-1}$ for 3 minutes. The fraction $<0.25 \mathrm{~mm}$ was collected to determine fraction $<0.25 \mathrm{~mm}$ by sedimentation, the fraction $>0.25 \mathrm{~mm}$ was dried at $105^{\circ} \mathrm{C}$ and then weighed. The aggregates remained on the sieve were next sieved in the solution of sodium hexameta phosphate $(0.05 \mathrm{M})$ until only sand particles remained on the sieve using the same device. Then it was dried at $105^{\circ} \mathrm{C}$ and weighed. The index of water stable aggregates, (WSA), was then determined as:

$$
\text { WSA }=\frac{W D S}{W D S+W D W}
$$

where;

WDS - weight of aggregates dispersed in the dispersing solution (M)

WDW - weight of aggregates dispersed in distilled water (M)

\section{Terrain analysis}

Terrain parameters of watershed were extracted using CartoDEM. Integrated algorithms were utilized to compute terrain parameters such as slope, aspect, flow direction, flow accumulation. The following terrain parameters such as slope, Terrain Wetness Index (TWI) and Stream Power Index (SPI) the average value 3x3 pixels of the samples sites was computed using ArcGIS 10.2.2

\section{Slope}

It is primary terrain attribute used to describe the steepness of the area. Mathematically it is the rise over run. The range of slope values in the watershed varies from 0 to 90 degrees.

\section{Terrain wetness index (TWI)}

It is one of the secondary terrain parameters also known as CTI (Compound Topographic Index), it quantifies the contribution of topography on the soil erosion generated at a particular sites. The terrain wetness index was computed as (Beven and Kirkby, 1993):

$$
\mathrm{TWI}=\ln (\mathrm{As} / \tan \beta)
$$

where,

$A=$ Upstream contributing area $\left(\mathrm{m}^{2}\right)$

$\beta=$ Local slope gradient

\section{Stream power index (SPI)}

It is the secondary terrain parameter. It represent the rate of depletion of energy by the flowing stream of water on the channel bed and basins, which determines the strength of the flowing water body to carry soil particles and sediments.

$$
\mathrm{SPI}=\ln (\mathrm{As} * \tan \beta)
$$

where,

A = Upstream contributing area $\left(\mathrm{m}^{2}\right)$

$\beta=$ Local slope gradient

ArcGIS 10.2 used for creating and using maps, compiling geographic data and managing geographic information in a database.

\section{Statistical analysis}

The multiple linear regression analysis was used to evaluate the relationships between the soil aggregation stability with soil properties and terrain variables. The simple correlation between the variables was assessed using Pearson correlation coefficient. Two factors with replication analyses of variance ANOVA procedures was computed to establish relationship between aggregate stability under various land use/land cover using statistical package (SPSS) version 16.0. (R Studio) was used for statistical and graphical techniques, that includes linear and multiple linear modeling, classical statistical tests.

\section{Results and Discussion}

\section{Land use/ land cover and terrain characteristics of the watershed}

Land use/land cover type map of the study area was prepared by visually interpreting the standard FCC of satellite data by onscreen digitization. The major land use/land cover types interpreted in the watershed were crop land, open forest, dense scrub, open scrub and settlement. 
Dense scrub (45.07 \%) formed the predominant land use/land cover type followed by agriculture (36.90\%) (Table 5; Figure 5). Analysis of soil aggregate stability data in the present study revealed that highest aggregate stability was found in dense scrub land with a mean value of 0.26 , followed by forest land (mean value of 0.23 ) and cropland (mean value of 0.22 ) respectively (Table 4). Lower soil aggregate stability in cropland may be attributed to frequent disturbances caused by human activities such as plowing as well as other inter cultural operations, which are very minimal or absent in case of scrub and forest lands. The elevation within the watershed varied from 1200 to $1927 \mathrm{~m}$ above MSL. Elevation range in the watershed of $>1713 \mathrm{~m}$ was categorized as upper hillslope and $<1489 \mathrm{~m}$ as lower and 1489 To $1713 \mathrm{~m}$ as mid-hillslope area. Within the entire study are TWI and SPI value ranges from 3.52-15.14 and 4.03-18.1 respectively (Figure $6 \& 7$ ). The watershed was characterized by highly rugged terrain with steep slope. Larger area (>85\%) of the watershed was characterized with slope of more than 25 percent, whereas 17 percent of the area had slope values greater than 60 percent (Table 6).

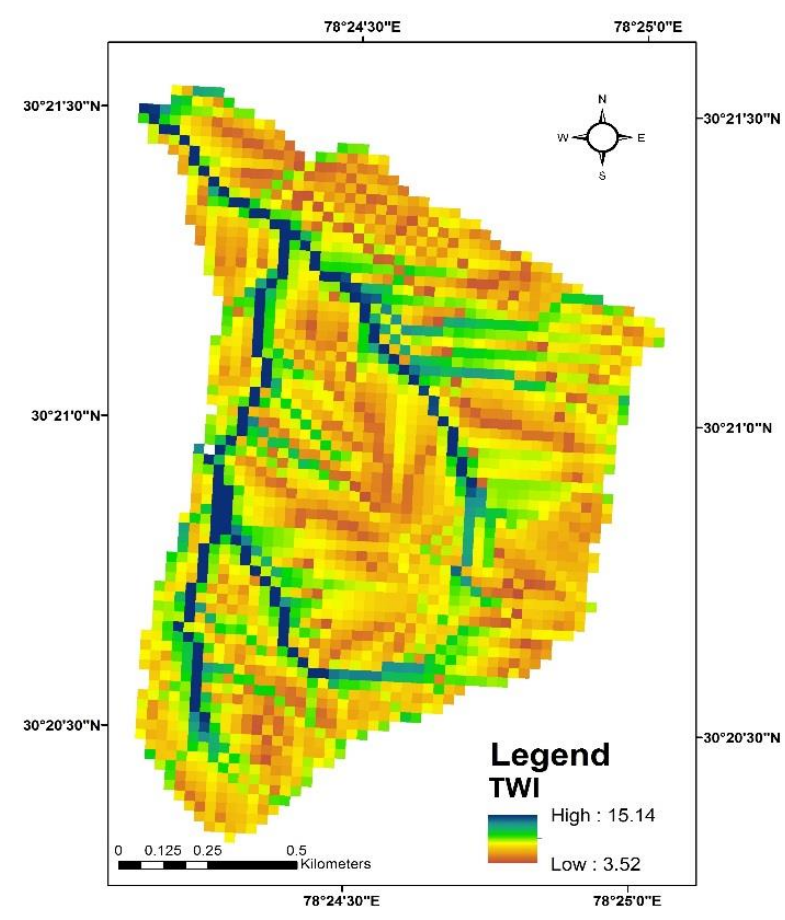

Figure 6. Terrain Wetness Index (TWI) map of the watershed

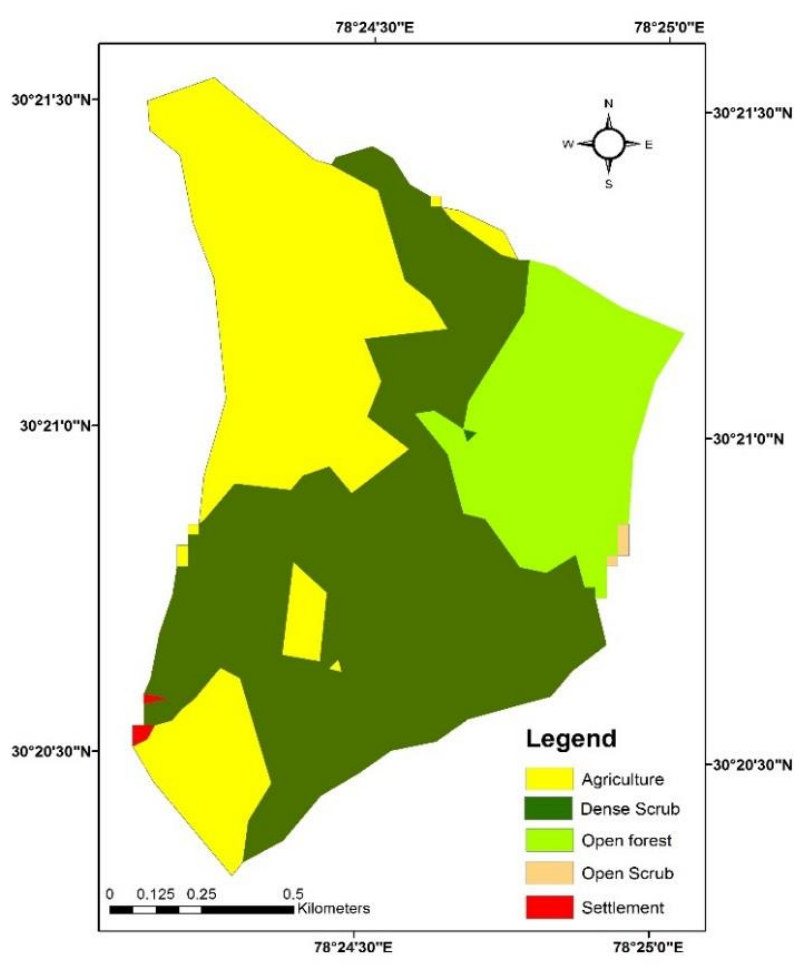

Figure 5. Land use land cover map showing various LU/LC units in the watershed

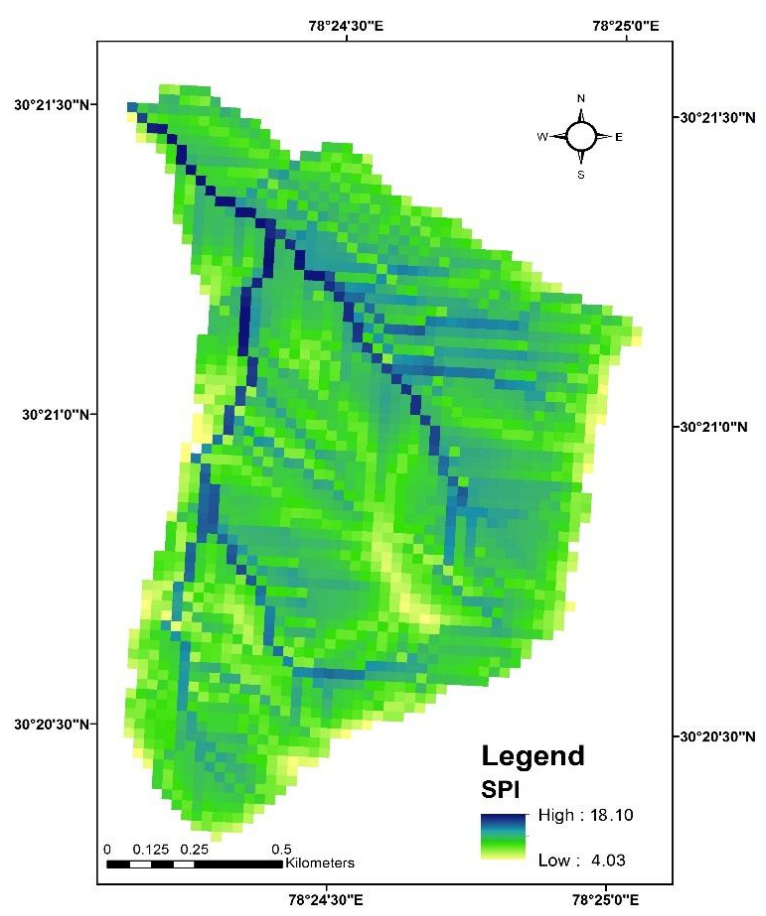

Figure 7. Stream Power Index (SPI) map of the watershed

Table 4. Distribution of aggregate stability in different land use with respect to hillslope units

\begin{tabular}{|c|c|c|c|c|c|c|c|}
\hline \multirow{3}{*}{ Land use/land cover } & \multicolumn{6}{|c|}{ Hillslope Units } & \multirow{3}{*}{$\begin{array}{c}\text { Aggregate Stability Value } \\
\text { with in study area } \\
\text { Mean } \\
\end{array}$} \\
\hline & \multicolumn{2}{|c|}{ Upper } & \multicolumn{2}{|c|}{ Middle } & \multicolumn{2}{|c|}{ Lower } & \\
\hline & Mean & SD & Mean & SD & Mean & SD & \\
\hline Crop land (12) & - & - & 0.28 & 0.18 & 0.16 & 0.09 & 0.22 \\
\hline Forest land (18) & 0.28 & 0.09 & 0.18 & 0.06 & - & - & 0.23 \\
\hline Dense Scrub (15) & 0.32 & 0.04 & 0.16 & 0.17 & 0.32 & 0.13 & 0.26 \\
\hline
\end{tabular}


Table 5. Watershed area under various land use / land cover classes

\begin{tabular}{ccc}
\hline Land use/land cover & Area in (Ha) & Area in (\%) \\
\hline Agriculture & 72.18 & 36.9 \\
Dense Scrub & 88.89 & 45.07 \\
Open Forest & 35.34 & 17.61 \\
Open Scrub & 0.36 & 0.14 \\
Settlement & 0.33 & 0.27 \\
\hline
\end{tabular}

Table 6. Watershed area under various slope classes

\begin{tabular}{ccc}
\hline Slope Class & Slope Value \% & Area in (\%) \\
\hline Nearly Level & $0-10$ & 1.49 \\
Gentle Sloping & $10-25$ & 12.98 \\
Moderate Slope & $25-40$ & 29.35 \\
Steep & $40-60$ & 39.16 \\
Very Steep & $>60$ & 17 \\
\hline
\end{tabular}

\section{Physico-chemical characteristics of soils}

The soil analysis revealed that the soils of the watershed are slightly acidic with a mean pH value of 6.01 . It containing high amount of soil carbon with an average value of 2.26 percent and nitrogen with a mean value of 0.18 percent (Table 3 ). The predominant soil textural class in the watershed was sandy loam to loam.

Table 3. Distribution of SOC, N, Sand, silt, clay and pH in different hillslope units

\begin{tabular}{cccccccc}
\hline Soil & \multicolumn{4}{c}{ Hillslope Units } & \multicolumn{2}{c}{ Lower } & Value with in entire \\
Variables & \multicolumn{3}{c}{ Upper } & \multicolumn{2}{c}{ Middle } & SDdy area \\
& \cline { 2 - 6 } & Mean & SD & Mean & SD & Mean & SD \\
\cline { 2 - 6 } Carbon & 2.44 & 0.50 & 2.25 & 0.61 & 2.11 & 0.59 & 2.27 \\
Nitrogen & 0.20 & 0.06 & 0.19 & 0.13 & 0.16 & 0.03 & 0.18 \\
Sand & 35.38 & 12.45 & 45.48 & 14.07 & 38.64 & 6.91 & 39.83 \\
Silt & 41.10 & 11.27 & 35.1 & 9.69 & 39.37 & 6.04 & 38.52 \\
Clay & 23.63 & 3.52 & 19.41 & 5.65 & 22.65 & 3.16 & 21.89 \\
pH & 6.06 & 0.30 & 6.01 & 0.30 & 5.97 & 0.38 & 6.01 \\
\hline
\end{tabular}

\section{Aggregate stability of soil}

Aggregate stability in various Land use/land cover

Several studies have been carried out to determine the influence of the land use of the soil, topographical position, and management practices on the soil organic matter (SOM) content and stability of soil aggregates (Lyneh, 1984; Cambardella et al., 1994; Bricchiet al., 2004; Annabie et al.,2017; Ouet al., 2017). Analysis of soil aggregate stability data in the present study revealed that highest aggregate stability was found in dense scrub land with a mean value of 0.26 , followed by forest land (mean value of 0.23 ) and cropland (mean value of 0.22 ) (Table 4). It has been observed that cropland soils had significantly lower soil aggregates stability than that of other land use types (Zhao et al., 2016). Zhang (2012) reported soil organic matter (SOM) contents in surface soils followed in a descending order of scrubland, grassland, woodland and cropland, respectively. Lower soil aggregate stability in cropland may be attributed to human activities such as plowing. Plowing can destroy the natural soil structure (Reicoskyet al., 1995) and the decomposition of SOC (Rovira and Greacen, 1957; Davidson and Ackerman, 1993). High soil organic carbon will bind the soil particles through the formation of various organo-mineral as well as organo-clay complexes thus resulting in soil aggregate high stability. SOM serves as a cementing in the soil aggregates development (Six et al. 2002). These complexes provide high aggregate stability because of their strong ability to withstand action of erosion causing forces mainly water, due to their strong binding action. The positive effect of high organic matter on aggregate stability are much prominent and distinct in soils with higher clay content, because of their synergistic effect in binding of molecules by formation of chemical bonds. Soil aggregation increases with an increase in SOM content and clay mineral in the soil (Bronick and Lal, 2005; Fernández-Ugalde et al., 2013). Several studies revealed a linear relationship between organic carbon content and water stable aggregates for various soils (Angers, 1992; Carter,1992).

Among the various hillslope positions, upper hillslope has no agricultural area. It is covered with natural pine forest and dense scrub. Soil of dense scrub land showed higher aggregate stability ranged from 0.16 (middle slope) to 0.32 (upper/lower hillslope) followed by soil in forest cover ranged from 0.18 (mid hillslope) to 0.28 (upper hillslope). In mid hillslope area of the watershed cropland showed the highest 
stability (0.28) followed by forest and dense scrub cover (Table 4). Agriculture is major land use in lower hillslope with dense scrub land in patches, where no forest cover was observed. In lower hillslope scrub land showed the highest values for soil aggregate stability followed by cropland (Amézketa, 1999) studied macro aggregation at various hillslope positions and observed higher aggregation in surface soil at the lower slope position as well as an increase in soil organic carbon (Stanchi et al., 2015) found higher aggregates stability in the soils due to lower erosion rate at lower hillslopes.

Land use / land cover types strongly influences distribution of soil organic carbon (SOC) contents in the soil (White et al., 2009; Fang et al., 2011). Soils under forest cover had high soil organic carbon than the soils of cropland. (Sreenivas et al., 2016) showed highest SOC density in forest soils than the agricultural land in India. SOC accumulation from vegetation biomass contributes to the enhancement of soil aggregation and vice versa (Six et al., 2000). In cropland soils, soil disturbance from tillage destabilizes aggregates, releasing intra-aggregate organic matter and increasing decomposition of soil carbon (Grandyand Robertson, 2006; Six et al., 1999, Six et al., 2000). It results decline in SOC in cropland and therefore poor aggregate stability in the soils of cropland. Besides this, SOC accumulation is also strongly influenced by soil erosion and deposition that differs at slope position in the watershed. Organic matter acts as major binding agent and stabilizer to natural soil aggregates (Greenland et al., 1962; Six et al., 2004).

In the present study, scrub land located in upper hillslope showed highest aggregate stability in the watershed. Forest soils had higher soil aggregate stability than the crop land attributed to the high SOC contents in the forest land. Forest land in upper hillslope had higher aggregate stability as these soils witnesses less surface runoff and eventually low soil erosion. Soils of crop land of mid-hillslope had high aggregate stability than the lower hillslope as it receive higher surface runoff water from upper hillslope area resulting removal of SOC from soil and these soils witness higher soil erosion rate. (Zhang et al., 2015) showed decrease in the surface runoff and soil erosion in forest land compared to crop land and fallow land in the Hilly Watershed of Southern China. Similarly, (Zhang et al., 2006) reported less SOC contents in toeslope (lower- slope) portions than those above the toe-slope (i.e. upper- and mid-slope portions) in the watershed. Soil aggregation and soil carbon accumulation differed between slope positions (Tang et al., 2010). (Liu et al. 2003) pointed out that terrain characteristics have significant impacts on soil C dynamics. Further, topographical influences on soil $\mathrm{C}$ can interact with management, resulting in altered responses to management such as tillage (Senthilkumar et al., 2009) and land use (Tan et al., 2004) depending on slope positions in the landscape.

\section{Aggregate stability relation with soil and terrain variables}

Topography significantly influences physical and chemical properties of soils. Terrain attributes derived from digital elevation models (DEMs) have been widely used in predicting soil properties (Camplig et al., 2002; Lai et al., 2006; Wang et al., 2007, Kumar and Singh, 2016). Spatial variation in SOC strongly influenced by the topography (McBratney et al., 2003; Schwanghart and Jarmer, 2011) and local terrain attribute algorithm better capture the spatial variation of SOC in the landscape (Behrens et al., 2010). In the study, Multiple Linear Regression Analysis was performed considering soil aggregate as dependent variable and all other factors as independent variable. Here, the correlation coefficient quantifies the linear association between the dependent and independent variable. The value of the coefficient (B1) shows the affect independent variable on the dependent variable. The P-value is used as a measure to reject null hypothesis, P-value of $5 \%(\mathrm{p}<0.05)$ or less is the generally accepted point at which to reject the null hypothesis. The coefficient (B1) and P-value are calculated to identify the best factors that can be used to model the change in soil aggregation. Regression analysis for AS prediction of different land use land cover types revealed varying influences of soil and terrain variables for prediction. Among the different land use type's regression models were able to predict AS prediction, with varying accuracy levels. $\left(R^{2}\right.$ values $\left(r^{2}=0.27\right),\left(r^{2}=0.75\right)$ and $\left(\mathrm{r}^{2}=0.95\right)$ respectively. higher soil aggregate stability found in scrub lands may be minimal or absent frequent disturbances caused by human activities such as plowing as well as other inter cultural operations, which are very common in crop land. The Prediction variables were found to be the same. But the level of significance varied much among the different land use land cover types with respect to AS.

An attempt was also made to study the relationship between various soil variables and the soil aggregate stability. Various soil properties like total soil carbon, total nitrogen, $\mathrm{pH}$, clay and silt were estimated by the laboratory analysis of soil samples. Among these variables, carbon and nitrogen were found to exhibit statistically significant $(\mathrm{p}<0.05)$ correlation with soil aggregate stability. Multiple linear regression model ( $\mathrm{r} 2=0.36)$ was developed using the various soil properties for the prediction of soil aggregate stability (Table 
7). Gulser (2018) analyzed water stable aggregates of surface cultivated soils and found clay, sand, $\mathrm{pH}$ and organic matter $(\mathrm{OM})$ contents as the most effective variables in predicting soil aggregate stability.

Table 7. Relationship between soil aggregate stability and different soil variables

\begin{tabular}{lcccc}
\hline Soil & \multicolumn{4}{c}{ Aggregate stability Vs Soil Variables } \\
\cline { 2 - 5 } variables & R2 & Intercept & $\beta 1$ & P-Value \\
\hline Carbon (C) & & -0.079 & 0.01 \\
Nitrogen (N) & & -0.609 & 0.009 \\
Clay (\%) & \multirow{2}{*}{0.36} & 0.69 & -0.0051 & 0.223 \\
Silt (\%) & & & -0.001 & 0.559 \\
\hline
\end{tabular}

Various soil and terrain parameters had significant relationship with soil aggregate stability and were further used for developing statistical model for predicting soil aggregate stability. Among the terrain variables slope gradient, curvature (profile and plan), topographic wetness index (TWI) and stream power index (SPI) are the most important variables influencing aggregate stability of soils (Walock and McCabe, 1995; Pennock, 2003). An analysis was attempted to study relationship between soil aggregate stability and terrain variables. Among the different terrain variables, elevation, TWI and SPI were found to have significant relationship with the soil aggregate stability. Regression model for the prediction of soil aggregate stability was also developed using these terrain variable $\left(r^{2}=0.37\right)$ (Table 8). Several studies described significant relationship between the terrain variables and soil aggregates stability (Rhoton and Duiker, 2008; Canton et al., 2009). Aggregate stability varies in different parts of the slope position and had a direct relationship with topographic derivatives (Rhoton et al., 2006; Canton et al., 2009; Tang et al., 2010). Zádorová et al. (2011) identified the plan curvature as the main variable influencing spatial distribution of soil organic carbon.

Table 8. Relationship between soil aggregate stability and different terrain variables

\begin{tabular}{|c|c|c|c|c|}
\hline \multirow{2}{*}{$\begin{array}{l}\text { Terrain } \\
\text { variables }\end{array}$} & \multicolumn{4}{|c|}{ Aggregate stability Vs Soil/Terrain Variables } \\
\hline & R2 & Intercept & $\beta 1$ & P-Value \\
\hline Elevation & & & 0.002 & 0.018 \\
\hline Slope & & & 0.080 & 0.578 \\
\hline TWI & 0.37 & -0.64 & -0.051 & 0.013 \\
\hline SPI & & & 0.0003 & 0.034 \\
\hline
\end{tabular}

The variables carbon, nitrogen, elevation, TWI and SPI having high correlation coefficient were selected. Multiple linear regression analysis using these variables yielded more accurate prediction model $\left(\mathrm{r}^{2}=0.50\right)$ compared to the models developed using the soil and terrain parameters separately (Table 9).

Table 9. Relationship between the aggregate stability and selected soil and terrain variables

\begin{tabular}{lcccc}
\hline Soil and Terrain & \multicolumn{3}{c}{ Aggregate stability Vs } & Soil/Terrain Variables \\
\cline { 2 - 5 } variables & R2 & Intercept & $\beta 1$ & P-Value \\
\hline Nitrogen & & & -0.154 & 0.434 \\
Carbon & & & -0.082 & 0.009 \\
Elevation & \multirow{2}{*}{0.50} & -0.266 & 0.0003 & 0.022 \\
TWI & & & 0.051 & 0.001 \\
SPI & & -0.019 & 0.246 \\
\hline
\end{tabular}

The following plots obtained after performing regression analysis clearly revealed the existence of linear relationship between Soil aggregation, carbon, nitrogen, elevation, TWI and SPI as well as the normal distribution of the variables in the watershed (Table 10). Multiple linear regression equation to model soil aggregate stability and residual vs fitted plot and normal Q-Q plot revealed that error is comparatively lesser than the previous models developed using all the soil properties as well as terrain parameters (Figure 8, 9, 10). Normal Q-Q plot analysis was carried out to estimate the error in statistical model analysis revealed lesser error values of model developed with soil and terrain variables.

Table 10. Multiple Linear Regression equations to predict soil aggregate stability

\begin{tabular}{lcc}
\hline Variables & Multiple Linear Regression & $\mathrm{R}^{2}$ \\
\hline Soil & YAS $=0.698-0.0795^{*}$ Carbon-0.6097*Nitrogen-0.005*Clay-0.001*Silt & 0.368 \\
Terrain & YAS $=-0.641+0.002 *$ Elevation+0.080*Slop-0.051*TWI+0.0003*SPI & 0.372 \\
Soil + Terrain & YAS=-0.266-0.154*Nitrogen-0.082*Carbon+0.051*TWI-0.019*SPI+0.0003*Elevation & 0.504 \\
\hline
\end{tabular}



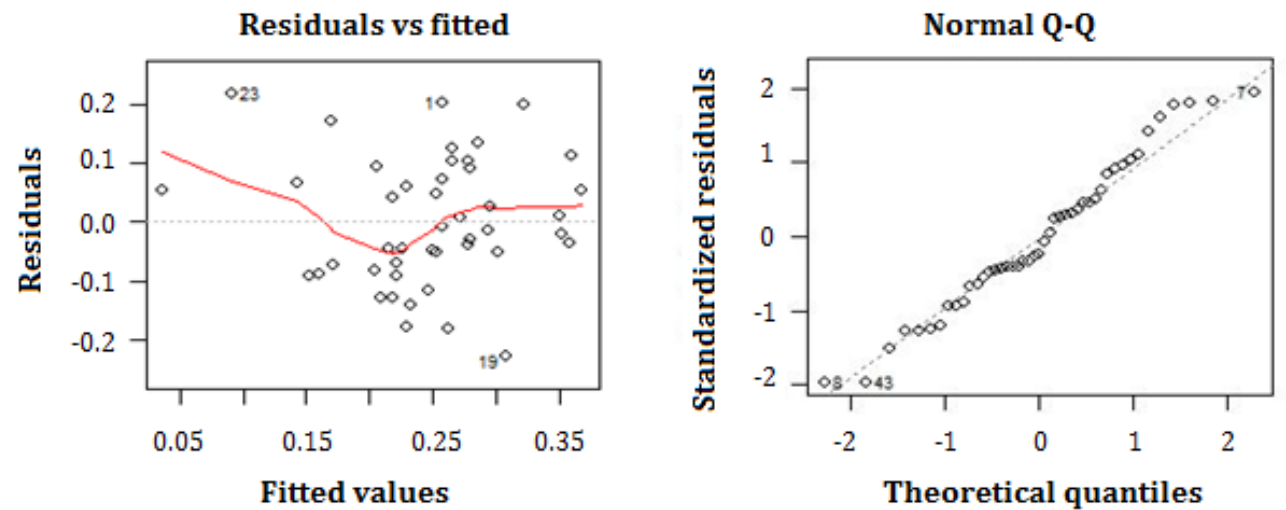

Figure 8. Soil aggregate stability with carbon, nitrogen, clay and silt as explanatory variable and the scatter plot and QQ plot were analyzed
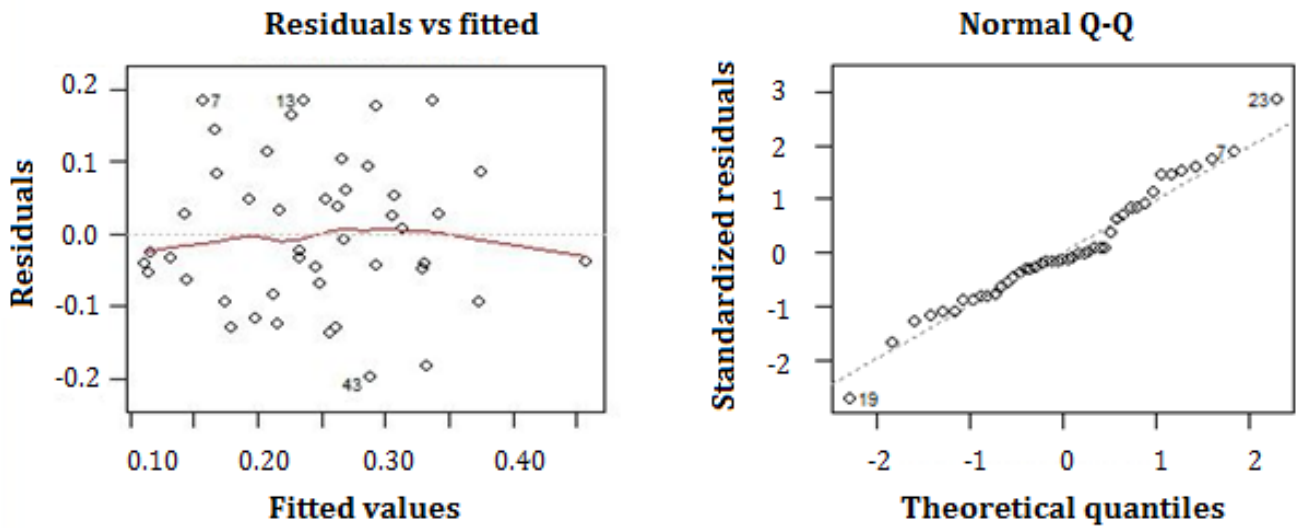

Figure 9. Soil aggregation with Elevation, slope, TWI and SPI as explanatory variable and the scatter plot and QQ plot were analyzed
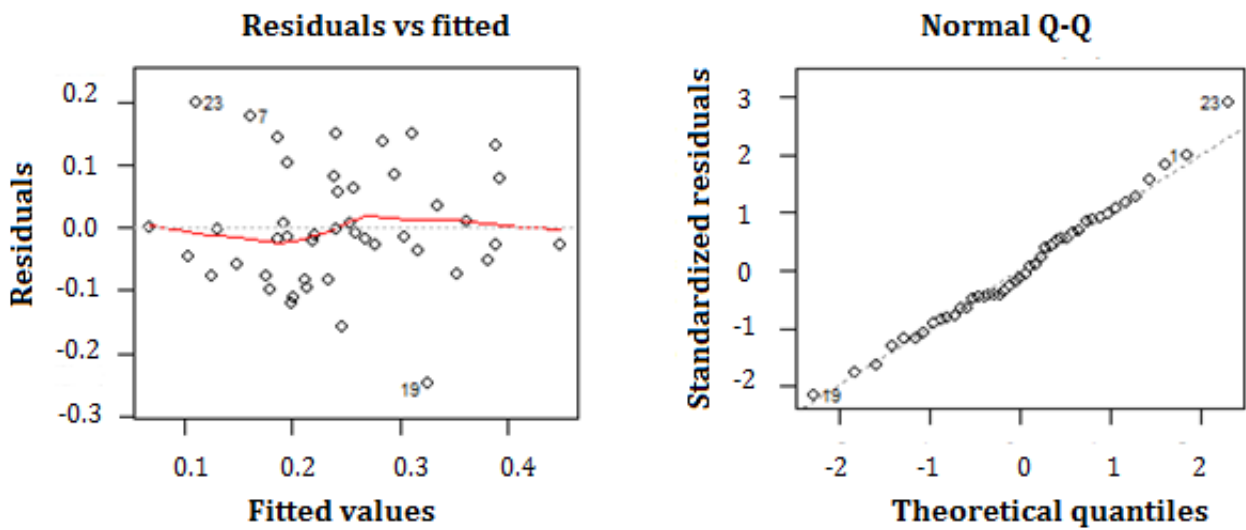

Figure 10. Soil aggregation with carbon, nitrogen, elevation TWI and SPI as explanatory variable and the scatter plot and QQ plot were analyzed

\section{Conclusion}

Aggregate stability of surface soil denote its resistance to susceptibility of soils. Changes in soil aggregate stability with respect to land use and topographic positons were investigated in Tehri Garhwal district of Uttarakhand state, India. Analysis revealed that the land use type had significant impact on the soil aggregate stability. Among the various land use /land cover classes, aggregate stability was found highest in dense scrub land with a mean vale of 0.26 ranged from 0.16 (middle slope) to 0.32 (upper/lower hillslope) followed by forest land (mean value of 0.23 ) ranged from 0.18 (mid hillslope) to 0.28 (upper hillslope) and lowest in crop land (mean value of 0.22 ) was found to be in the range of 0.16 (lower hillslope) to 0.28 (mid hillslope). Soil aggregate stability was found to be highest in dense scrub and lowest in crop land. This may be due to the high organic carbon rooting and proportion of vegetative cover in dense scrub, which limits/restricts the deteriorating impact of raindrops and runoff water on soil aggregates. 15 Aggregate 
stability was also correlated with soil and terrain variables, of which, carbon and nitrogen among soil variables and elevation, TWI and SPI among the terrain variables showed highest correlations, significant $\mathrm{p}$ values and less error. Multiple linear regression analysis using soils and terrain variables resulted much better prediction model $\left(\mathrm{r}^{2}=0.50\right)$ in comparison to the models developed using the soil and terrain parameters separately. The knowledge generated from this study will help us in identifying areas which are vulnerable to soil loss as well as nutrient due to the lower stability of aggregates. The relationships established between aggregate stability and terrain parameters will help us in spatial mapping of aggregate stability status with optimum number of sampling thus avoiding extensive sampling in these hilly mountainous terrains where inaccessibility is an issue due to terrain characteristics.

\section{Acknowledgment}

Authors are thankful to the Director, Indian Institute of Remote Sensing for providing necessary facilities to carry out the research work. We are sincerely thanks for financial support under EOAM Project on "Mountain Ecosystem Processes and Services in North-Western Himalaya" from ISRO, Department of Space, Govt. of India.

\section{References}

Amézketa, E., 1999. Soil aggregate stability: a review. Journal of Sustainable Agriculture 14(2-3): 83-151.

Angers, D.A., Pesant, A., Vigneux, J., 1992. Early cropping-induced changes in soil aggregation, organic matter, and microbial biomass. Soil Science Society of America Journal 56(1): 115-119.

Annabie, M., Raclot, D., Bahri, H., Bailly, J.S., Gomez, C., Le Bissonnais, Y., 2017. Spatial variability of soil aggregate stability at the scale of an agricultural region in Tunisia. Catena 153: 157-167.

Anornu, G.K.., Kabo-Bah, A., Kortats, B.K., 2012. Comparability studies of high and low resolution digital elevation models for watershed delineation in the tropics: case of Densu River Basin of Ghana. International Journal of Cooperative Studies 1(1): 9-14.

Ballabio, C., Panagos, P., Monatanarella, L., 2016. Mapping topsoil physical properties at European scale using the LUCAS database. Geoderma 261: 110-123.

Barthès, B., Albrecht, A., Asseline, J., De Noni, G., Roose, E., 1999. Relationship between soil erodibility and topsoil aggregate stability or carbon content in a cultivated Mediterranean highland (Aveyron, France). Communications in Soil Science and Plant Analysis 30(13-14):1929-1938.

Barthès, B., Azontonde, A., Boli, B.Z., Prat, C., Roose, E., 2000. Field-scale run-off and erosion in relation to topsoil aggregate stability in three tropical regions (Benin, Cameroon, Mexico). European Journal of Soil Science 51(3): 485-495.

Behrens, T., Zhu, A.X., Schmidt, K., Scholten, T., 2010. Multi-scale digital terrain analysis and feature selection for digital soil mapping. Geoderma 155(3-4): 175-185.

Berhe, A.A., Harte, J., Harden, J.W., Torn, M.S., 2007. The significance of the erosion-induced terrestrial carbon sink. BioScience 57(4): 337-346.

Beven, K.J., Kirkby, M.J., 1993. A physically-based, variable contributed area model of basin hydrology. Hydrological Science Bulletin 24(1): 43-69.

Bricchi, E., Formia, F., Espósito, G., Riberi, L., Aquino, H., 2004. The effect of topography, tillage and stubble grazing on soil structure and organic carbon levels. Spanish Journal of Agricultural Research 2(3): 409-418.

Bronick, C.J., Lal, R., 2005. Manuring and rotation effects on soil organic carbon concentration for different aggregate size fractions on two soils in northeastern Ohio, USA. Soil and Tillage Research 81(2): 239-252.

Cambardella, C.A., Moorman, T.B., Parkin, T.B., Karlen, D.L., Novak, J.M., Turco, R.F., Konopka, A.E., 1994. Field-scale variability of soil properties in central Iowa soils. Soil Science Society of America Journal 58(5): 1501-1511.

Campling, P., Gobin, A., Feyen, J., 2002. Logistic modeling to spatially predict the probability of soil drainage classes. Soil Science Society of America Journal 66(4): 1390-1401.

Cantón, Y., Solé-Benet, A., Asensio, C., Chamizo, S., Puigdefábregas, J., 2009. Aggregate stability in range sandy loam soils relationships with runoff and erosion. Catena 77(3): 192-199.

Carter, M.R., 1992. Influence of reduced tillage systems on organic matter, microbial biomass, macro-aggregate distribution and structural stability of the surface soil in a humid climate. Soil and Tillage Research 23(4): 361372.

Case, B.S., Meng, F.R., Arp, P.A., 2005. Digital elevation modelling of soil type and drainage within small forested catchments. Canadian Journal of Soil Science 85(1): 127-137.

Cerdá, A., 1996. Soil aggregate stability in three Mediterranean environments. Soil Technology 9(3): $133-140$.

Das, S., Patel, P.P., Sengupt, S., 2016. Evaluation of different digital elevation models for analyzing drainage morphometric parameters in a mountainous terrain: a case study of the Supin-Upper Tons Basin, Indian Himalayas. SpringerPlus 5: 1544.

Davidson, E.A., Ackerman, I.L., 1993. Changes in soil carbon inventories following cultivation of previously untilled soils. Biogeochemistry 20(3): 161-193. 
Emadodin, I., Reiss, S., Bork, H.R., 2009. A study of the relationship between land management and soil aggregate stability (case study near Albersdorf, Northern-Germany). Journal of Agriculture and Biological Sciences 4: 48-53.

Fang, X., Xue, Z., Li, B., An, S., 2011. Soil organic carbon distribution in relation to land use and its storage in a small watershed of the Loess Plateau, China. Catena 88(1): 6-13.

Fernández-Ugalde, O., Barré, P., Hubert, F., Virto, I., Girardin, C., Ferrage, E., Chenu, C., 2013. Clay mineralogy differs qualitatively in aggregate-size classes: clay-mineral-based evidence for aggregate hierarchy in temperate soils. European Journal of Soil Science 64(4):410-422.

Florinsky, IV., 2012. The Dokuchaev hypothesis as a basis for predictive digital soil mapping (on the 125th anniversary of its publication). Eurasian Soil Science 45(4): 445-451.

Gerrard, A.J., 1981. Soils and landforms: An integration of geomorphology and pedology. George Allen \& Unwin (Publishers) Ltd.

Grandy, A.S., Robertson, G.P., 2006. Aggregation and organic matter protection following tillage of a previously uncultivated soil. Soil Science Society of America Journal 70(4): 1398-1406.

Greenlan, D.J., Lindstrom, G.R., Quirk, J.P., 1962. Organic materials which stabilize natural soil aggregates. Soil Science Society of America Journal 26(4): 366-371.

Gülser, C. 2018. Predicting aggregate stability of cultivated soils. Journal of Scientific and Engineering Research 5 (11): 252-255

Gülser, C., 2006. Effect of forage cropping treatments on soil structure and relationships with fractal dimensions. Geoderma 131(1-2): 33-44.

Hancock, G.R., Martinez, C., Evans, K.G., Moliere, D.R., 2006. A comparison of SRTM and high-resolution digital elevation models and their use in catchment geomorphology and hydrology: Australian examples. Earth Surface Processes and Landforms 31(11): 1394-1412.

Jain, A.O., Thaker, T., Chaurasia, A., Patel, P., Singh, A. K., 2017. Vertical accuracy evaluation of SRTM-GL1, GDEM-V2, AW3D30 and CartoDEM-V3. 1 of 30-m resolution with dual frequency GNSS for lower Tapi Basin India. Geocarto International 33(11): 1237-1256.

Kasper, M., Buchan, G.D., Mentler, A., Blum, W.E.H., 2009. Influence of soil tillage systems on aggregate stability and the distribution of C and N in different aggregate fractions. Soil and Tillage Research 105(2): 192-199.

Kienzle, S., 2004. The effect of DEM raster resolution on first order, second order and compound terrain derivatives. Transaction in GIS 8(1): 83-111.

Kroetsch, D., Wang, C., 2007. Particle size distribution. In: Soil Sampling and Methods of Analysis, Carter, M.R., Gregorich, E.G. (Eds.). Second Edition. CRC Press. Boca Raton, FL. pp.713-726.

Kumar, S., Singh, R.P., 2016. Spatial distribution of soil nutrients in a watershed of Himalayan landscape using terrain attributes and geostatistical methods. Environmental Earth Sciences 75: 473.

Lai, Y.K., Zhou, Q.Y., Hu, S.M., Martin, R.R., 2006. Feature sensitive mesh segmentation. In: Proceedings of the 2006 ACM symposium on Solid and physical modeling. 6-8 June 2006, Cardiff, Wales, UK. pp. 17-25.

Le Bissonnais, Y., 1996. Aggregate stability and assessment of soil crustability and erodibility: I. Theory and methodology. European Journal of Soil Science 67(1): 11-21.

Liu, S., Bliss, N., Sundquist, E., Huntington, T.G., 2003. Modeling carbon dynamics in vegetation and soil under the impact of soil erosion and deposition. Global Biogeochemical Cycles 17(2).

Lynch, J.M., 1984. Interactions between biological processes, cultivation and soil structure. Plant and Soil 76(1-3): 307318.

Mataix-Solera, J., Cerdà, A., Arcenegui, V., Jordán, A., Zavala, L.M., 2011. Fire effects on soil aggregation: a review. EarthScience Reviews 109(1-2): 44-60.

Nimmo, J.R., Perkins, K.S., 2002. Aggregate stability and size distribution, In: Methods of Soil Analysis, Part 4- Physical methods. Dane, J.H., Topp, G.C. (Eds.). Soil Science Society of America, Madison, Wisconsin, USA. pp.317-328.

Ou, Y., Rousseau, A.N., Wang, L., Yan, B., 2017. Spatio-temporal patterns of soil organic carbon and $\mathrm{pH}$ in relation to environmental factors-A case study of the Black Soil Region of Northeastern China. Agriculture, Ecosystems \& Environment 245: 22-31.

Pennock, D.J., 2003. Terrain attributes, landform segmentation, and soil redistribution. Soil and Tillage Research 69(12): $15-26$.

Poch, R.M., Antúnez, M., 2010. Aggregate development and organic matter storage in Mediterranean mountain soils. Pedosphere 20(6): 702-710.

Reicosky, D.C., Kemper, W.D., Langdale, G., Douglas, Jr.C.L., Rasmussen, P.E., 1995. Soil organic matter changes resulting from tillage and biomass production. Journal of Soil and Water Conservation 50(3): 253-261.

Rhoton, F.E., Duiker, S.W., 2008. Erodibility of a soil drainage sequence in the loess uplands of Mississippi. Catena 75(2): 164-171.

Rhoton, F.E., Emmerich, W.E., Goodrich, D.C., Miller, S.N., McChesney, D.S., 2006. Soil geomorphological characteristics of a semiarid watershed. Soil Science Society of America Journal 70(5):1532-1540.

Rovira, A.D., Greacen, E.L., 1957. The effect of aggregate disruption on the activity of microorganisms in the soil. Australian Journal of Agricultural Research 8(6):659-673. 
Santillana, J.R., Makinano-Santillana, M., Ampayon, B.C., Del Norte, A., 2016. Vertical Accuracy Assessment of 30-M Resolution Alos, Aster, and Srtm Global Dems OverNortheastern Mindanao, Philippines. The International Archives of the Photogrammetry, Remote Sensing and Spatial Information Sciences, Volume XLI-B4, 2016. XXIII ISPRS Congress, 12-19 July 2016, Prague, Czech Republic. pp. 149-156.

Saran, S., Sterk, G., Peters, P., Dadhwal, V.K., 2010. Evaluation of digital elevation models for delineation of hydrological response units in a Himalayan watershed. Geocarto International 25(2): 105-122.

Schwanghart, W., Jarmer, T., 2011. Linking spatial patterns of soil organic carbon to topography-a case study from south-eastern Spain. Geomorphology 126(1-2): 252-263.

Senthilkumar, S., Kravchenko, A.N., Robertson, G.P., 2009. Topography influences management system effects on total soil carbon and nitrogen. Soil Science Society of America Journal 73(6): 2059-2067.

Shaver, T.M., Peterson, G.A., Ahuja, L.R., Westfall, D.G., Sherrod, L.A., Dunn, G., 2002. Surface soil physical properties after twelve years of dryland no-till management. Soil Science Society of America Journal 66(4):1296-1303.

Shi, Z.H., Yan, F.L., Li, L., Li, Z.X., Cai, C.F., 2010. Interrill erosion from disturbed and undisturbed samples in relation to topsoil aggregate stability in red soils from subtropical China. Catena 81(3): 240-248.

Shrestha, B.M., Singh, B.R., Sitaula, B.K., Lal, R., Bajracharya, R.M., 2007. Soil aggregate-and particle-associated organic carbon under different land uses in Nepal. Soil Science Society of America Journal 71(4): 1194-1203.

Six, J., Bossuyt, H., Degryze, S., Denef, K., 2004. A history of research on the link between (micro) aggregates, soil biota, and soil organic matter dynamics. Soil and Tillage Research 79(1): 7-31.

Six, J., Elliott, E.T., Paustian, K., 1999. Aggregate and soil organic matter dynamics under conventional and no-tillage systems. Soil Science Society of America Journal 63(5): 1350-1358.

Six, J., Feller, C., Denef, K., Ogle, S., de MoraesSa, J.C., Albrecht, A., 2002. Soil organic matter, biota and aggregation in temperate and tropical soils-Effects of no-tillage. Agronomie 22(7-8): 755-775.

Six, J., Paustian, K., Elliott, E.T., Combrink, C., 2000. Soil structure and organic matter: I. Distribution of aggregate-size classes and aggregate-associated carbon. Soil Science Society of America Journal 64(2): 681-689.

Smith, M.P., Zhu, A.X., Burt, J.E., Stiles, C., 2006. The effects of DEM resolution and neighborhood size on digital soil survey. Geoderma 137(1-2): 58-69.

Sreedevi, P.D., Owais, S., Khan, H.H., Ahmed, S., 2009. Morphometric analysis of a watershed of South India using SRTM data and GIS. Journal of the Geological Society of India 73(4): 543-552.

Sreenivas, K., Dadhwal, V.K., Kumar, S., Sri Harsha, G., Mitran, T., Sujatha, G., Suresh, G.J.R., Fyzee, M.A., Ravisankar, T., 2016. Digital mapping of soil organic and inorganic carbon status in India. Geoderma 269: 160-173.

Stanchi, S., Falsone, G., Bonifacio, E., 2015. Soil aggregation, erodibility, and erosion rates in mountain soils (NW Alps, Italy). Solid Earth 6(2): 403-414.

Tan, Z.X., Lal, R., Smeck, N.E., Calhoun, F.G., 2004. Relationships between surface soil organic carbon pool and site variables. Geoderma 121(3-4): 187-195.

Tang, X., Liu, S., Liu, J., Zhou, G., 2010. Effects of vegetation restoration and slope positions on soil aggregation and soil carbon accumulation on heavily eroded tropical land of Southern China. Journal of Soils and Sediments 10(3): 505-513.

Tejada, M., Gonzalez, J.L., 2006. The relationships between erodibility and erosion in a soil treated with two organic amendments. Soil and Tillage Research 91(1-2): 186-198.

Wang, Q.K., Wang, S.L., 2007. Soil organic matter under different forest types in Southern China. Geoderma 142(3-4): 349-356.

White II, D.A., Welty-Bernard, A., Rasmussen, C., Schwartz, E., 2009. Vegetation controls on soil organic carbon dynamics in an arid, hyperthermic ecosystem. Geoderma 150(1-2): 214-223.

Wolock, D.M., McCabe Jr, G.J., 1995. Comparison of single and multiple flow direction algorithms for computing topographic parameters in TOPMODEL. Water Resources Research 31(5): 1315-1324.

Yadav, V., Malanson, G., 2007. Progress in soil organic matter research litter decomposition, modelling, monitoring and sequestration. Progress in Physical Geography: Earth and Environment 31(2):131-154.

Zádorová, T., Jakšík, O., Kodešová, R., Penížek, V., 2011. Influence of terrain attributes and soil properties on soil aggregate stability. Soil and Water Research 6(3): 111-119.

Zhang, J.H., Liu, S.Z., Zhong, X.H.,2006. Distribution of soil organic carbon and phosphorus on an eroded hill slope of the range land in the northernTibet Plateau, China. European Journal of Soil Science 57(3): 365-371.

Zhang, X.W., Ming-xiang, X.U., Chen-di, S.H.I, 2012. Soil organic carbon sequestration rate and its influencing factors in farmlands of semi-arid regions-A case study in Zhuanglang County, Gansu Province. Plant Nutrition and Fertilizer Science 18(5): 1089-1098.

Zhang, Z., Sheng, L., Yang, J., Chen, X.A., Kong, L., Wagan, B., 2015. Effects of Land Use and Slope Gradient on Soil Erosion in a Red Soil Hilly Watershed of Southern China. Sustainability 7(10): 14309-14325.

Zhao, W., Zhang, R., Huang, C., Wang, B., Cao, H., Koopal, L.K., Tan, W., 2016. Effect of different vegetation cover on the vertical distribution of soil organic and inorganic carbon in the Zhifanggou Watershed on the loess plateau. Catena 139: 191-198.

Zhu, G.Y., Shangguan, Z.P., Deng, L., 2017. Soil aggregate stability and aggregate-associated carbon and nitrogen in natural restoration grassland and Chinese red pine plantation on the Loess Plateau. Catena 149: 253-260. 